\title{
Pengaruh lama perendaman dan konsentrasi etanol terhadap rendemen pada pembuatan minyak esensial kulit buah jeruk pontianak
}

\begin{abstract}
The Effect of Immersion Duration and Ethanol Concentration towards the Yield in the Production of Pontianak Orange Peels Essential Oil
\end{abstract}

\author{
Welly Deglas ${ }^{1)}$ \\ ${ }^{1)}$ Teknologi Pangan, Politeknik Tonggak Equator Pontianak \\ e-mail : wellydeglas@yahoo.com
}

Informasi Artikel:

Dikirim: 30/08/2019; ditinjau: 31/08/2019; disetujui: 30/09/2019

\begin{abstract}
The purpose of this study was to determine how much influence of different immersion duration (1 day, 2 days and 3 days) and ethanol concentration (50\%, 70\% and 90\%) on the yield in the production of essential oils made from Pontianak orange peels. The study was conducted using a Completely Randomized Design (CRD) with factorial pattern: A factor was the level of soaking time (1 day, 2 days, 3 days), and B factor was the ethanol concentration (50\%, 70\% and 90\%) of 3 replications. The highest yield of Pontianak orange peel essential oil was produced in the treatment of immersion for 3 days with ethanol concentration of $90 \%$ (A3B3) which was $8.89 \%$. While the lowest yield was obtained in the treatment of 1-day immersion with the ethanol concentration of $50 \%$ (A1B1) which was equal to 5.01\%. The immersion duration and ethanol concentration affect the colour and $\mathrm{pH}$, whereas the aroma was not significantly affected among samples.
\end{abstract}

Keywords: orange peel, essential oil, ethanol

\begin{abstract}
ABSTRAK
Tujuan dari penelitian ini adalah untuk mengetahui seberapa besar pengaruh lama perendaman (1 hari, 2 hari dan 3 hari) dan konsentrasi etanol (50\%, 70\% dan 90\%) yaitu terhadap rendemen pada pembuatan minyak esensial kulit buah jeruk Pontianak. Penelitian dilakukan dengan menggunakan Rancangan Acak Lengkap (RAL) pola Faktorial: Faktor A adalah level lama perendaman (1 hari, 2 hari, 3 hari), dan Faktor B adalah konsentrasi etanol (50\%, 70\% dan 90\%) sebanyak 3 ulangan. Rendemen tertinggi minyak esensial kulit jeruk Pontianak dihasilkan pada perlakukan lama perendaman 3 hari dengan konsentrasi etanol 90\% (A3B3) yaitu sebesar $8.89 \%$. Sedangkan rendemen terendah diperoleh pada perlakukan lama perendaman 1 hari dengan konsentrasi etanol 50\% (A1B1) yaitu sebesar 5.01\%. Lama waktu perendaman dan konsentrasi etanol berpengaruh terhadap warna dan $\mathrm{pH}$. Sedangkan pada aroma tidak terdapat perbedaan nyata diantara setiap sampel.
\end{abstract}

Kata kunci : kulit jeruk, minyak essensil, ethanol

\section{PENDAHULUAN}

Jeruk Pontianak (Citrus nobilis) adalah jenis jeruk siam yang telah lama menjadi salah satu komoditas unggulan tanaman hortikultura di Pontianak Kalimantan Barat. Jeruk Pontinak telah terkenal secara luas dan diakui memiliki rasa yangkhas, berkulit tipis, manis dengan 
sedikit rasa asam. Keunggulan jenis jeruk siam ini antara lain popularitasnya yang sudah terkenal baik di dalam maupun luar negeri khususnya ASEAN. Tanaman jeruk (Citrus nobilis) adalah tanaman buah tahunan yang berasal dari Asia. Cina dipercaya sebagai tempat pertama kali jeruk tumbuh. Sejak ratusan tahun yang lalu, jeruk sudah tumbuh di Indonesia baik secara alami atau dibudidayakan. Tanaman jeruk yang ada di Indonesia adalah peninggalan orang Belanda yang mendatangkan jeruk dari Amerika dan Itali. Prospek agribisnis jeruk di Indonesia cukup bagus karena potensi lahan produksi yang luas (Bayuardi, 2010).

Memasuki awal tahun 2018, harga Jeruk Siam Sambas mulai merangkak naik. Kenaikan harga jeruk ini, tentunya menjadi berkah tersendiri dan menjadi kabar yang menggembirakan bagi para petani jeruk di Kabupaten Sambas. Sehingga terus bersemangat dalam merawat tanaman jeruk yang dimiliki. Satu diantara petani jeruk, masyarakat setempat mengungkapkan, kenaikan harga jeruk ini diperkirakannya sudah terjadi sejak dua pekan terakhir di penghujung tahun 2017. Jadi sudah berlangsung sekitar dua mingguan. Harga jeruk mulai naik, dari yang dulunya cuma Rp 3.000 per kilo, sekarang sudah menjadi Rp 7.500 per kilo, itu untuk buah dengan kualitas grade A. Pria yang sudah menekuni menanam Jeruk Siam Sambas sejak lebih dari 13 tahun silam ini berharap, agar kondisi kenaikan harga jeruk tersebut berlangsung lama. Sehingga bisa terus memberikan kesejahteraan bagi petani. Semakin meningkatnya permintaan jeruk di Pontianak maka limbah kulit jeruk yang dihasilkan juga semakin banyak dan tidak termanfaatkan, padahal didalam kulit jeruk masih memiliki kandungan limonene, yang merupakan senyawa di dalam minyak atsiri kulit jeruk dan sangat diperlukan dalam berbagai macam industri dan memiliki nilai ekonomis. Dalam penelitian ini penulis ingin melihat hasil rendmen minyak esensial pada pada kulit jeruk dengan perlakuan lama perendaman dan konsentrasi etanol terhadap rendemen pada pembuatan minyak esensial kulit buah jeruk Pontianak.

Minyak atsiri yang dihasilkan bervariasi sekitar $1,5 \%$ sampai $3 \%$. Secara tradisional metode yang sering digunakan dipedesaan di Indonesia adalah destilasi kukus. Penggunaan suhu tinggi dan adanya air dapat menyebabkan kerusakan minyak atsiri yang dihasilkan karena panas yang tinggi dan terjadinya reaksi hidrolisis dengan air, sehingga dapat menurunkan kualitas minyak atsiri yang dihasilkan (Nuryoto dkk., 2011; Prianto dkk., 2013).

Permintaan bahan untuk rempah-rempah dan parfum secara alami meningkat seiring pertambahan populasi,terutama untuk makanan, minuman dan produk kecantikan karena antimikroba dan antioksidannya properti (Bakali et al., 2008; Tongnuanchan dan Benjakul, 2014). Masalah keamanan pangan (yang tidak mengandung zat berbahaya di dalamnya)jangka pendek dan jangka panjang) telah membuat konsumen lebih cenderung mengkonsumsi makanan alami, salah satunya adalaah minyak jeruk. Citrus nobilis Lour. var. nobilis adalah nama ilmiah dari spesies jeruk. Daun, bunga, dan kulit jeruk adalah komponen yang bisa jadidiekstraksi menjadi minyak esensial $(0,95 \%)$. Minyak jeruk diekstraksi dengan berbagai metode ekstraksi sepert imetode mekanis: pemerasan, tekan; Metode tradisional: ekstraksi dengan pelarut; distilasi denganair; Metode modern: ekstraksi dengan bantuan microwave atau dengan pelarut karbon dioksida dan microwave hydro-distillation digunakan untuk mempersingkat waktu distilasi. Beberapa metode tersebut secara signifikan dapat meningkatkan komposisi dan hasil minyak atsiri (Asghari, Touli dan Mazaheritehrani, 2012; Moradalizadeh, Samadi dan Rajaei, 2013; Nitthiyah et al., 2017).

Minyak esensial dari jeruk mengandung D-limonene, yang merupakan senyawa utama yang bertanggung jawab untuk menghilangkan bau udara,mengurangi stres, membersihkan dekongestan hidung, antipenuaan, dan sifat detoksifikasi karena 
tingginya sifat antioksidan dan antimikroba (Bermejo, Llosá dan Cano, 2011). Studi karakterisasi senyawa volatil pada minyak kulit telah dilakukan (Dharmawan et al., 2007; Dharmawan, Kasapis dan Curran, 2008;Dharmawan et al., 2008), tetapi hasilnya tidak memberikan informasi tentang senyawa aktif-aroma. Publikasi terbaru oleh Fischer, Grab dan Schieberle (2008) yang dimulai dengan pencarian identifikasi aroma-aktif senyawa jeruk di Pontianak.

\section{METODE PELAKSANAAN}

\section{Bahan}

Bahan baku yang digunakan dalam penelitian ini adalah kulit jeruk siam Pontianak, etanol dan air

\section{Alat}

Adapun alat yang digunakan pada penelitian ini adalah kompor gas, tissu, spatula, toples, pisau, zester/parut baskom, gelas ukur dan blender.

\section{Metode}

Penelitian ini terdiri terdiri dari beberapa tahap yaitu dari proses pengupasan kulit jeruk, pengeringan, penecilan ukuran, pemanasan, perendaman dan penguapan alkohol. Ambil bagian luar kulit jeruk menggunakan pisau atau parut menggunakan zester, keringkan bagian kulit jeruk yang telah diparut dengan oven selama 2 jam dengan suhu $80^{\circ} \mathrm{C}$, setelah dikeringkan masukan kulit jeruk kering tersebut ke food processor (mesin pengolah makanan) atau dengan blender, hangatkan etanol dan masukkan air hangat ke dalam mangkuk. Suhunya harus cukup hangat dan tidak terlalu panas (kira-kira $32^{\circ} \mathrm{C}$ ). Letakkan botol etanol di air hangat dan rendam selama 20 menit, masukan etanol kedalam toples sesuai perlakukan konsentrasi etanol $(50 \%$, $70 \%$ dan $90 \%$ ) rendam kulit jeruk dengan etanol hangat dan kocok selama beberapa saat, kemudian masukan parutan atau gilingan kulit jeruk di toples, tuangkan etanol sampai sepenuhnya merendam kulit jeruk dan tutup sampai rapat dan kocok kembali dengan selama beberapa menit, diamkan campuran sesuai perlakukan selama (1 hari, 2 hari, 3 hari), saring campuran gunakan filter kopi atau kain cheesecloth dan hitung jumlah minyak esensial yang diperoleh, setelah selesai buka tutup toples dan tutupi dengan kain atau tisu untuk menguapkan alkohol dan diamkan beberapa hari, hal ini memungkinkan sisa alkohol di campuran menguap. Jika semua alkohol sudah hilang, yang tersisa hanyalah minyak jeruk.

\section{Rancangan penelitian}

Penelitian dilakukan dengan menggunakan Rancangan Acak Lengkap (RAL) pola Faktorial: Faktor A adalah level lama perendaman (1 hari, 2 hari, 3 hari), dan Faktor B adalah konsentrasi etanol (50\%, $70 \%$ dan $90 \%$ ) sebanyak 3 ulangan.

\section{Analisis data}

Data yang diperoleh dalam penelitian ini akan dianalisa menggunakan Analysis of Variance (ANOVA). Jika terdapat perbedaan antar sampel maka akan dilanjutkan dengan uji beda nyata menggunakan analisis Tukey's pada taraf signifikansi $1 \%$ dan $5 \%$. Pengujian terdiri dari pengujian kadar air, uji organoleptik terdiri dari uji skoring dan uji hedonik

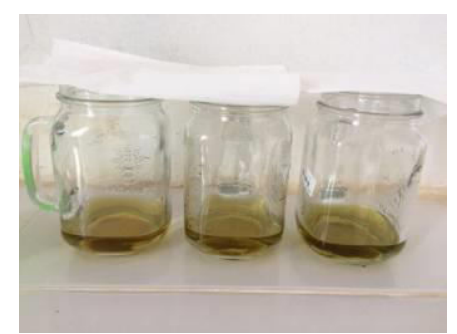

Gambar 1. Peremdaman kulit jeruk

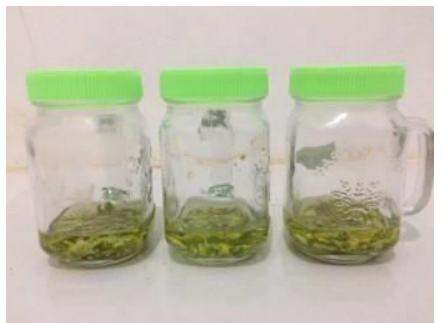

Gambar 2. Peremdaman kulit jeruk 


\section{HASIL DAN PEMBAHASAN}

\section{Rendemen}

Tabel 1. Rerata rendemen minyak esensial kulit buah jeruk Pontianak (\%)

\begin{tabular}{cccccc}
\hline $\begin{array}{c}\text { Lama } \\
\text { Peremdaman }\end{array}$ & $\begin{array}{c}\mathbf{B}_{1} \\
(\text { Etanol 50\%) }\end{array}$ & $\begin{array}{c}\mathbf{B}_{\mathbf{2}} \\
(\text { Etanol 70\%) }\end{array}$ & $\begin{array}{c}\mathbf{B}_{\mathbf{3}} \\
(\text { Etanol 90\%) }\end{array}$ & Jumlah & Rerata \\
\hline $\mathrm{A}_{1}$ & $5.01 \mathrm{c}$ & $5.53 \mathrm{c}$ & $6.11 \mathrm{c}$ & 16.65 & $5.55 \mathrm{p}$ \\
$\mathrm{A}_{2}$ & $6.11 \mathrm{~b}$ & $6.44 \mathrm{~b}$ & $7.42 \mathrm{~b}$ & 19.97 & $6.66 \mathrm{q}$ \\
$\mathrm{A}_{3}$ & $7.89 \mathrm{a}$ & $8.12 \mathrm{a}$ & $8.89 \mathrm{a}$ & 24.90 & $8.30 \mathrm{r}$ \\
\hline Jumlah & 19.01 & 20.09 & 22.42 & - & - \\
Rerata & 6.34 & 6.70 & 7.47 & - & - \\
\hline
\end{tabular}

Keterangan : angka yang diikuti huruf yang berbeda menunjukan adanya beda nyata, berdasarkan uji jarak berganda Duncan pada taraf 5\%.

Penelitian pembuatan minyak
esensial dilakukan dengan metode
perendaman larutan etanol $\begin{array}{r}\text { dengan } \\ \text { konsentrasi etanol }(50 \%, 70 \% \text { dan } 90 \%)\end{array}$
selama $1-3$ hari, dengan tujuan untuk
menghasilkan rendemen tertinggi selama
proses perendaman dengan pelarut etanol. Rendemen tertinggi minyak esensial kulit jeruk Pontianak dihasilkan pada perlakukan lama perendaman 3 hari dengan konsentrasi etanol 90\% (A3B3) yaitu sebesar $8.89 \%$. Sedangkan rendemen terendah diperoleh pada perlakukan lama perendaman 1 hari dengan konsentrasi etanol 50\% (A1B1) yaitu sebesar $5.01 \%$. Dalam penelitian ini menunjukkan bahwa semakin tinggi konsentrasi etanol yang digunakan maka minyak esensial kulit jeruk yang dihasilkan semakin tinggi. Adanya penggunaan konsentrasi etanol yang tinggi pelarut ektraksi akan menghasilkan rendemen lebih tinggi dibandingkan dengan menggunakan etanol dengan konsentrai rendah. Hal ini dikarenakan etanol bersifat polar, dikarenakan etanol berfungsi untuk melarutkan resin sedangkan n-heksan melarutkan minyak (Taifan et al., 2013).

Lama waktu perendaman juga mempengaruhi hasil dari rendemen, semakin lama proses ektrasi maka rendemen yang dihasilkan semakin tinggi. Hal ini disebabkan karena proses ekstraksi yang dilakukan secara terus-menerus. Penyarian yang dilakukan berulang-ulang dengan jumlah pelarut yang relatif konstan, menyebabkan komponen atau senyawa kimia dalam sampel akan terisolasi dengan baik. Metode ini sangat sederhana digunakan karena proses ekstraksinya terjadi secara sempurna sehingga hasil ekstrak yang diperoleh juga lebih banyak serta dengan adanya proses pemanasan yang dapat membantu mempercepat proses ekstraksi. Setyowati, menyatakan bahwa hal ini terjadi karena semakin tinggi suhu ekstraksi akan menyebabkan gerakan molekul semakin cepat, begitu juga dengan adanya sirkulasi (pergerakan) pelarut.

Pelarut yang digunakan dalam penelitian ini adalah pelarut etanol dan air. Menurut Trifani (2012), etanol dan air digunakan sebagai pelarut karena bersifat polar, universal dan mudah didapat. Senyawa polar merupakan senyawa yang larut didalam air. Perbedaan konsentrasi etanol dan lama perendaman mempengaruhi jumlah rendemen yang dihasilakan ini dipengaruhi kemapuan pelarut dalam melarutkan komponen-komponen dalam kulit jeruk Pontianak. Kelarutan suatu zat terlarut dalam pelarut tergantung pada tingkat kepolaran pelarut dan zat terlarut. Dimana komponen polar akan larut dalam pelarut polar serta komponen non polar akan larut dalam pelarut non polar (Amir, 2013). 
Uji Organoleptik terhadap warna minyak esensial kulit buah jeruk

Tabel 2. Uji organoleptik terhadap warna minyak esensial kulit buah jeruk Pontianak

\begin{tabular}{cccccc}
\hline $\begin{array}{c}\text { Lama } \\
\text { Peremdaman }\end{array}$ & $\begin{array}{c}\mathbf{B}_{\mathbf{1}} \\
(\text { Etanol 50\%) }\end{array}$ & $\begin{array}{c}\mathbf{B}_{\mathbf{2}} \\
(\mathbf{E t a n o l ~ 7 0 \% )})\end{array}$ & $\begin{array}{c}\mathbf{B}_{\mathbf{3}} \\
(\text { Etanol 90\%) }\end{array}$ & Jumlah & Rerata \\
\hline $\mathrm{A}_{1}$ & $4,23 \mathrm{c}$ & $4,17 \mathrm{c}$ & $4,20 \mathrm{c}$ & 12,60 & 4,20 \\
$\mathrm{~A}_{2}$ & $3,80 \mathrm{~b}$ & $3,87 \mathrm{bc}$ & $3,83 \mathrm{~b}$ & 11,50 & 3,83 \\
$\mathrm{~A}_{3}$ & $2,87 \mathrm{a}$ & $2,90 \mathrm{a}$ & $2,73 \mathrm{a}$ & 8,50 & 2,83 \\
\hline Jumlah & 10,90 & 10,94 & 10,76 & - & - \\
Rerata & 3,63 & 3,65 & 3,59 & - & - \\
\hline Keterangan : & & 4. Jingga & & & \\
1. Tidak jingga & & 5. Sangat Jingga & & & \\
2. Sedikit jingga & & & &
\end{tabular}

Warna merupakan faktor yang dapat digunakan sebagai indikator kesegaran atau kematangan suatu produk. Warna merupakan daya tarik terbesar untuk menikmati aroma makanan. Warna dalam makanan dapat meningkatkan penerimaan konsumen tentang sebuah produk.

Berdasarkan hasil pengujian terhadap warna pada sampel minyak esensial kulirt jeruk terdapat perbedaan sangat nyata diantara setiap sampel yang ada. Hal ini diketahui dari perhitungan Analisis Of Varian (ANOVA) yang menunjukan bahwa F.hitung > F.tabel. dimana, diperoleh hasil sampel pengujian nilai $\mathrm{F}$ hitung untuk warna adalah 79,48 sedangkan F.tabel 1\% sebesar 2,16 dan 5\% sebesar 1,75 , sehingga dilanjutkan dengan uji LSD.

Dari hasil pengujian lama perlakukan sangat berpengaruh nyata terhadap warna dari minyak esensial kulit jeruk yang diberi dari warna sangat jingga hingga tidak berwarna jingga. Hasil dari penilaian panelis semakin lama waktu perendaman etanol maka warna minyak esensial yang dihasilkan semakin sedikit jingga yaitu sebesar 2,73. Pada proses perendaman dengan larutan etanol akan terjadi perubahan warna pada kulit jeruk Pontianak yang disebabkan oleh adanya degradasi pigmen. Terdegradasinya pigmen klorofil menyebabkan warna dari pigmen-pigmen lain (antosianin, xantofil dan karoten) muncul. Adanya perubahan pigmen inilah yang menyebabkan warna kulit buah berubah dari awalnya hijau menjadi oranye, sehingga setelah dilakukan proses ekstraksi kulit jeruk Pontianak yang dihasilkan memiliki nilai kecerahan yang berbeda.

Uji Organoleptik terhadap aroma minyak esensial kulit buah jeruk

Tabel 3. Uji organoleptik terhadap warna minyak esensial kulit buah jeruk Pontianak

\begin{tabular}{cccccc}
\hline $\begin{array}{c}\text { Lama } \\
\text { Peremdaman }\end{array}$ & $\begin{array}{c}\mathrm{B}_{1} \\
(\text { Etanol 50\%) }\end{array}$ & $\begin{array}{c}\mathrm{B}_{2} \\
(\text { Etanol 70\%) }\end{array}$ & $\begin{array}{c}\mathrm{B}_{3} \\
(\text { Etanol 90\%) }\end{array}$ & Jumlah & Rerata \\
\hline $\mathrm{A}_{1}$ & 3,83 & 3,93 & 3,90 & 11,66 & 3,89 \\
$\mathrm{~A}_{2}$ & 3,90 & 3,90 & 3,83 & 11,63 & 3,88 \\
$\mathrm{~A}_{3}$ & 3,83 & 3,83 & 3,87 & 11,53 & 3,84 \\
Jumlah & 11,56 & 11,66 & 11,6 & - & - \\
Rerata & 3,85 & 3,89 & 3,87 & - & - \\
\hline Keterangan : & & & &
\end{tabular}

Aroma atau bau menentukan kelezatan suatubahan agar dapat diterima atau ditolak panelis. Aroma yang dihasilkan dari makanan banyak menentukan kelezatan bahan pangan tersebut. Aroma merupakan bau yang sangat subjektif karena setiap 
orang mempunyai sensitifitas dan kesukaan yang berbeda (Meilgaard et al., 2000).

Berdasarkan hasil pengujian terhadap aroma pada sampel minyak esensial kulirt jeruk tidak terdapat perbedaan nyata diantara setiap sampel yang ada. Hal ini diketahui dari perhitungan Analisis of Varian (ANOVA) yang menunjukan bahwa F.hitung < F.tabel. dimana, diperoleh hasil sampel pengujian nilai $\mathrm{F}$ hitung untuk warna adalah 0,27 sedangkan F.tabel $1 \%$ sebesar 2,16 dan $5 \%$ sebesar 1,75 ,
Dari hasil pengujian lama waktu perlakukan dan konsemtrasi etanol tidak berpengaruh nyata terhadap aroma dari minyak esensial kulit jeruk. Dari skor yang diberikan dari tidak beraroma jeruk sampai dengan sangat beraroma jeruk rata-rata panelis menilai produk 3,74-3,89 yaitu beraroma jeruk. Etanol mempunyai aroma khas yang tidak terlalu kuat sehingga ditutupi oleh aroma yang terdapat pada kulit jeruk. Sehingga rata-rata panelis menilai aroma produk beraroma jeruk.

pH

Tabel 4. Rerata $\mathrm{pH}$ minyak esensial kulit buah jeruk Pontianak

\begin{tabular}{cccccc}
\hline $\begin{array}{c}\text { Lama } \\
\text { Peremdaman }\end{array}$ & $\begin{array}{c}\mathrm{B}_{1} \\
(\text { Etanol 50\%) }\end{array}$ & $\begin{array}{c}\mathrm{B}_{2} \\
(\text { Etanol 70\%) }\end{array}$ & $\begin{array}{c}\mathrm{B}_{3} \\
(\text { Etanol 90\%) }\end{array}$ & Jumlah & Rerata \\
\hline $\mathrm{A}_{1}$ & $4,71 \mathrm{c}$ & $4,74 \mathrm{c}$ & $4,75 \mathrm{c}$ & 14,20 & 4,73 \\
$\mathrm{~A}_{2}$ & $4,22 \mathrm{~b}$ & $4,26 \mathrm{~b}$ & $4,25 \mathrm{~b}$ & 12,73 & 4,24 \\
$\mathrm{~A}_{3}$ & $3,87 \mathrm{a}$ & $3,68 \mathrm{a}$ & $3,88 \mathrm{a}$ & 11,43 & 3,81 \\
Jumlah & 12,80 & 12,68 & 12,88 & - & - \\
Rerata & 4,27 & 4,23 & 4,29 & - & - \\
\hline
\end{tabular}

Keterangan : angka yang diikuti huruf yang berbeda menunjukan adanya beda nyata, berdasarkan uji jarak berganda Duncan pada taraf $5 \%$.

$\mathrm{pH}$ atau derajat keasaman digunakan untuk menyatakan tingkat keasaaman atau basa yang dimiliki oleh suatu zat, larutan atau benda. $\mathrm{pH}$ normal memiliki nilai 7 sementara bila nilai $\mathrm{pH}>7$ menunjukkan zat tersebut memiliki sifat basa sedangkan nilai $\mathrm{pH}<7$ menunjukkan keasaman. $\mathrm{pH} 0$ menunjukkan derajat keasaman yang tinggi, dan $\mathrm{pH} 14$ menunjukkan derajat kebasaan tertinggi. Umumnya indicator sederhana yang digunakan adalah kertas lakmus yang berubah menjadi merah bila keasamannya tinggi dan biru bila keasamannya rendah.

Selain menggunakan kertas lakmus, indicator asam basa dapat diukur dengan $\mathrm{pH}$ meter yang bekerja berdasarkan prinsip elektrolit /konduktivitas suatu larutan. Sistem pengukuran $\mathrm{pH}$ mempunyai tiga bagian yaitu elektroda pengukuran $\mathrm{pH}$, elektroda referensi dan alat pengukur impedansi tinggi. Istilah $\mathrm{pH}$ berasal dari "p", lambang matematika dari negative logaritma, dan "H", lambang kimia untuk unsur Hidrogen. Defenisi yang formal tentang $\mathrm{pH}$ adalah negative logaritma dari aktivitas ion Hydrogen. $\mathrm{pH}$ adalah singkatan dari power of Hydrogen.

Hasil rerata analisa total $\mathrm{pH}$ dapat dilihat pada Tabel 6. Hasil analisa total $\mathrm{pH}$ pada tabel menunjukkan terdapat perbedaan yang nyata antara kajian lama waktu perendaman dan konsentrasi etanol, bahwa semakin lama waktu perendaman dan semakin besar konsentrasi etanol, total $\mathrm{pH}$ pada ekstrak kulit jeruk Pontianak semakin turun. Hal ini disebabakan karena pada proses perendaman enzim yang terdapat pada kulit jeruk Pontianak diinaktifkan melalui uap panas, sedangkan pada proses perendaman terjadi transfer panas dari pelarut (etanol) pada bahan, sehingga komponen bahan akan terekstrak lebih banyak, sehingga total $\mathrm{pH}$ nya turun. Hal ini sesuai dengan literatur, semakin murni suatu komponen bahan pangan maka tingkat keasaman suatu bahan akan semakin rendah, kerena komponen lain yang ada didalam bahan hilang. Kemampuan ekstrak 
antibakteri suatu bahan akan lebih aktif pada $\mathrm{pH}$ rendah, karena pada kondisi tersebut sel mempertahankan $\mathrm{pH}$ konstan didalam sel.

\section{KESIMPULAN}

Dari hasil penelian pengaruh lama perendaman (1 hari, 2 hari dan 3 hari) dan konsentrasi etanol (50\%, 70\% dan 90\%) yaitu terhadap rendemen pada pembuatan minyak esensial kulit buah jeruk Pontianak dapat disimpulkan sebagai berikut :

1. Semakin tinggi konsentrasi etanol yang digunakan maka minyak esensial kulit jeruk yang dihasilkan semakin tinggi, karena penggunaan konsentrasi etanol yang tinggi pelarut ektraksi akan menghasilkan rendemen lebih tinggi dibandingkan dengan menggunakan etanol dengan konsentrai rendah.

2. Lama waktu perendaman juga mempengaruhi hasil dari rendemen, semakin lama proses ektrasi maka rendemen yang dihasilkan semakin tinggi. Hal ini disebabkan karena proses ekstraksi yang dilakukan secara terusmenerus.

3. Lama waktu perendaman etanol berpengaruh terhadap uji organoleptik terhadap warna dan tidak berpengaruh terhadap warna. Semakin lama waktu perendaman etanol maka warna minyak esensial yang dihasilkan semakin sedikit jingga yaitu sebesar 2,73.

4. $\mathrm{pH}$ minyak esensial kulit jeruk dipengaruhi oleh lama waktu perendaman dan konsentrasi etanol, semakin lama waktu perendaman dan semakin besar konsentrasi etanol, total pH pada ekstrak kulit jeruk Pontianak semakin turun.

\section{DAFTAR PUSTAKA}

Amir, A.N. \& Puspita, F.L. (2013). Pengambilan oleoresin dari limbah ampas jahe industri jamu (pt.sido muncul) dengan metode ekstraksi. Jurnal Teknologi Kimia dan Industri, 2(3)
Asghari, J., Touli, C. K., \& Mazaheritehrani, M. (2012). Microwave-assisted hydrodistillation of essential oils from Echinophora platyloba DC. Journal of Medicinal Plants Research,6(28), 4475-4480.

Bakkali, F., Averbeck, S., Averbeck, D., \& Idaomar, M. (2008). Biological effects of essential oils-a review. Food and chemical toxicology, 46(2), 446-475.

Bayuardi, W. (2010). Komoditas jeruk pontianak

http://docplayer.info/73595153-Ipendahuluan-jeruk-pontianak-citrusnobilis-adalah-jenis-jeruk-siam-yangtelah-lama-menjadi.html. Diakses pada tanggal 18 Maret 2018.

Bermejo, A., Llosá, M. J., \& Cano, A. (2011). Analysis of bioactive compounds in seven citrus cultivars. Food Science and Technology International, 17(1), 5562.

Dharmawan, J., Kasapis, S., \& Curran, P. (2008). Characterization of volatile compounds in selected citrus fruits from Asia-Part II: Peel Oil. Journal of Essential Oil Research,20(1), 2124.

Dharmawan, J., Kasapis, S., Curran, P., \& Johnson, J. R. (2007). Characterization of volatile compounds in selected citrus fruits from Asia. Part I: freshly-squeezed juice. Flavour and Fragrance Journal, 22(3), 228-232..

Dharmawan, J., Kasapis, S., Sriramula, P., Lear, M. J., \& Curran, P. (2008). Evaluation of aroma-active compounds in Pontianak orange peel oil (Citrus nobilis Lour. Var. microcarpa Hassk.) by gas chromatography- olfactometry, aroma reconstitution, and omission test. Journal of Agricultural and Food Chemistry, 57(1), 239-244..

Fischer, A., Grab, W., \& Schieberle, P. (2008). Characterisation of the most odour-active compounds in a peel oil extract from Pontianak oranges (Citrus nobilis var. Lour. microcarpa 
Hassk.). European Food Research and Technology, 227(3), 735-744.

Gomez, K. A., \& Gomez, A.A. (1984). Statistical procedures for agricultural research. New York: John Will and Sons.

Hikmah, N. (2007). Rendemen dan Kualitas Minyak Atsiri Jahe (Zingibern)

Koswara, S. (2009). Teknologi pengolahan telur (teori dan praktek). eBookPangan.com.

Meilgaard, M., Civille, G.V., \& Carr B.T. (1999). Sensory evaluation techniques. Boca Raton:CRC Press.

Moradalizadeh, M., Samadi, N., \& Rajaei, P. (2013). Comparison of hydrodistillation, microwave hydrodistillation and solvent-free microwave methods in analysis of the essential oils from aerial parts of Haplophyllum robustum Bge. by GC/MS method. Int. J. Adv. Biol. Biomed. Res, 1(9), 1058-1067.

Nitthiyah, J., Nour, A. H., Kantasamy, R., \& Akindoyo, J. O. (2017). Microwave assisted hydrodistillation-An overview of mechanism and heating properties. Aust. J. Basic Appl. Sci, 11, 22-29.

Prianto, H., Retnowati, R., \& Juswono, U.P. (2013). Isolasi dan karakterisasi dari minyak bunga cengkeh.

Soelarso. (1996). Budidaya jeruk. Kanisius, Yogyakarta.

Taifan,W.E., Ivander, H. B\& Gunawan S. (2013). Pemisahan dan pemurnian phythalic acid ester dari minyak nyamplung. Jurnal Teknik Pomits, 2(2), 296-298

Tongnuanchan, P., \& Benjakul, S. (2014). Essential oils: extraction, bioactivities, and their uses for food preservation. Journal of food science, 79(7), R1231-R1249.

Trifani. (2012). Ekstraksi pelarut cair-cair. http://awjee. Diakses pada tanggal 10 Januari 2019

Winarno, F.G. (2002). Kimia pangan dan gizi. Jakarta: PT. Gramedia Pustaka Utama. 